\section{Senior Citizens and the Elderly Homes: A Survey from Kathmandu}

\section{Pradeep Acharya *}

\begin{abstract}
During the study information about the existing state of the seven elderly homes around Kathmandu, Bhaktapur and Kavrepalanchowk district was collected during OctoberNovember, 2007 on behalf of Geront World Nepal, Kathmandu. An attempt has been made to come across physical, economic status of different homes, their problems and challenges as well as the personal feelings of senior citizens living in there. The survey has tried to clarify the problems and challenges of elderly homes and the elders. Effort has been provided to see whether the elderly homes are helpful in providing proper care and support for the senior citizens. An analysis of four data sets (interview of 61 senior citizens out of total 122 in 7 homes, interview of all seven home's authorized persons, published/unpublished profile of the homes, and interview of key informants) as well as field observation shows significant positive effects of homes on the life of senior citizen. The survey results indicate that in number of respects elderly homes are favorable for the residents and the society as a whole despite of some problems, particularly for those who are uncomfortable in their family.
\end{abstract}

Key words: Seniors citizens, Homes, Retirement, Health

Mr. Pradeep Acharya is the Chairman of the Geront World Nepal, a NGO in Kathmandu and a part time Lecturer for Applied Sociology in Kantipur City College, Kathmandu

\section{Introduction}

Birth, infancy, adolescence, youth, old age and death are very familiar stages in the natural process of human life. In order to promote the welfare of senior citizen, the tenth five-year plan of the government of Nepal has specified some objectives, strategies and programs. According to the plan, government's main objectives are to guarantee a comfortable, secured and honored life for senior citizens as well as the utilization of their experience, knowledge, and skills. To fulfill such objectives the plan has emphasized the participation of senior citizens in policy making, right based guarantee for their needs, legal reforms, coordination of NGOs, local authorities and civil society, as well as the encouragement of model old age homes and establishment of geriatric ward in regional and zonal hospitals as the major strategies. Besides, including senior citizen related chapters in school curriculum, review of the existing senior citizen allowance, updating of records and social insurance are the other strategies put so forth. Programs specific to these objectives and strategies involve the provision for religious, entertaining discourses, income generation, promotional materials for increasing honor and respect and subsidy in public transport and health care etc.

We are rich in the culture of paying respect to our elders and aged, however, our social culture is being broken by the changing context of the world, desire for a small family, poverty and urbanization process (MWCSW, 2002). In such circumstances, the society seems to have empathized the problems and needs of the elderly and hence have attempted, though not sufficient, to ease their life. Current senior citizen policies are mainly concerned with encouraging NGOs in establishment and operation of elderly homes, providing special privileges to them who set up such homes as well as developing specific volunteer programs and contacts with 
schools so as to increase the feeling of respects towards the elderly from children as well as to create a family environment for elderly in old age homes (Upadhya, 2063). Elderly homes, religious sites are the only destination for senior citizens out of their family during the old age. Different activities from the side of government, NGOs and individuals are being done for the senior citizens. However, many of them are still deprived of proper care and support and basic need for comfortable survival.

The main objective of the study was to collect information about the existing state of elderly homes around the Kathmandu valley and the feelings of the resident elders in each home. I surveyed the physical, economic status of different homes, their problems and challenges as well as the personal feelings of senior citizens living in, the seven elderly homes situated in Kathmandu, Bhaktapur and Kavrepalanchowk district during October-November, 2007 on behalf of Geront World Nepal, Kathmandu, Nepal. An attempt has been made to clarify the problems and challenges of elderly homes and the elders. Effort has been provided to see whether the elderly homes are helpful in providing proper care and support for the senior citizens. An analysis of four data sets (interview of 61 senior citizens out of total 122 in 7 homes, interview of all seven home's authorized persons, published/unpublished profile of the homes, and interview of key informants) as well as field observation shows significant positive effects of homes on the life of senior citizen. The survey results indicate that in number of respects elderly homes are favorable for the residents and the society as a whole despite of some vital problems.

\section{Ageing and the Old Age in the Wider Context}

Ageing is a natural phenomenon and an inevitable process. Every living being born, develop, grow old and dies. Ageing is a process of gradual change in physical appearance and mental situation that cause a person to grow old. Ageing is such a mystery that is still not clearly defined even by the sciences. As the birth is an event and the pregnancy a process of it, old age is an event and ageing is its process. As soon as a man is born, ageing starts. This process continues forward by every second, day, weeks, months and years. Different countries of the world term a man as an old after crossing certain age depending on prevailing socio-cultural norms and values. Almost countries have declared sixty years of age while it is sixty-five in Nepal. Besides, wrinkled face, grey hair, loosed teeth, weak condition of sense are other characteristics feature of old age (Bhandari, 2061). Whatever the age limitation set by countries depending on the time, situation and place, everyone in general easily understand who the old people are.

Elderly people have to cope with various expectations on the part of younger generations concerning example of happy and peaceful life and the way to prepare themselves to enter the next world. Old age is the age of long and wide world and life experience. Aged ones as persons who express the truth to the world. Mental sufferings of the elderly are; agitation due to health problems, sorrows caused by departure from beloved ones or things, doubt concerning the nature of present and next life (Bhanman, 2006). Hence, the ageing, old age and problems of senior citizen are much more associated with spiritualism or spirituality rather than merely with the medical, economic and social issue.

Revolutions regarding long life occurred during the twentyfirst century. Average life expectancy at birth in 1950s moved up from 20 years to 66 years in 2002 and more 10 years will be added in 2050. Old population seems to be a major problem in the developing countries (UNOMadrid,2002). It is a fact that human techno-cultural progress made so far is still not capable to stop ageing and death but 
has succeeded in lowering the process of ageing. Population statistics shows that the number of elderly has been increasing because of increment in the average life expectancy at birth. In Nepal, according to CBS (2001), the population above sixty years of age comprised $5.8 \%$ of total population in the national census 2048B.S. while after ten years in 2058B.S. it increased to $6.5 \%$.

In Nepal, the Vedic tradition still governs family values and the elderly citizens are largely loved, revered and taken care of. However, with economic pressure resulting in migration of youth across border in search of works, the elderly population are left at home $\mathrm{n}$ rural hills, and the in laws consider them inactive, burdensome and passive recipients of love and support (MOWCSW, 2002). Old age is not a problem in itself but it becomes a problem when the obvious physical and mental changes brought by old age make men unable to do their own necessary basic things. Hence, the issue of senior citizen and old age should be addressed appropriately as other social problems in society.

\section{The Main Concern; Care of the Senior Citizens}

Records and evidence suggest that the origin and development of old age homes of a kind in Nepal started since 1938B.S. However its actual establishment was made in 2030B.S. Nepal has not been influenced by the first conference on elderly people in Vienna but once the UN declared 1999A.D. as the international year of elders, Nepal has shown interest in this sector from the part of NGOs and civil society (Upadhya, 2063).

MOWCSW (2061) has listed 52 organizations established to work for senior citizen in one or another form from the part of both government and non-government sector. Besides it has a list of three international organization working directly or/and for the sake of senior citizens.
One of the major functions of a universal socio-cultural institution family is to provide due care of children and the elderly and it is a fact that almost senior citizens of Nepal seem to have been taking care by their family. However, Shrestha (2004) noted that older people in Nepal live in a state of paradox. On the one hand, the traditional culture accord respect, deference and status to elderly persons to such a high degree those younger persons often feel suffocated and repressed by the presence of older generation.

Nuclear families have come into being probably because of material aspects and growing tendency of individualism among people rather than spiritualism. Consumerism has given rise to needless imitation of western countries and the Nepalese people seem to have lost the traditional value. The concept of elderly people living peacefully with the family has become a thing of the past. People are not fully aware of its consequences. Family cohesion is coming under pressure of generation gap between parents and children especially in urban areas (Ghimire/Dwadi, 2056). This reality further intensifies the issue whether the family or some other institution should take care of the senior citizens of a society i.e. family or the elderly homes.

No institution or agency have cared to adopt the "right based" approach in dealing with elderly person's issues as they have done with other sectors of the population e.g. children, women, Maoist etc. It has been limited to nominal "old age allowance” (Shrestha, 2004). Main concern of the care of senior citizen is nothing more than easing their lives in whatever way it is possible. Therefore, whatever the circumstances behind the problem or whoever set responsible for the care of senior citizen, the universally accepted social value is "the society for all ages" i.e. people of all ages have equal right to live a full life. For this, the society has to practically make a best possible alternative by improving the 
existing practice and attempt being made so far regarding the issue, which, most probably, could be the situation specific combination of both i.e. family plus the elderly homes.

\section{The Elderly Homes; Profile and Problems}

The seven elderly homes surveyed during the study represent a distinctness of their own. The following table shows the carrying capacity and the presently occupied seats.

Table 1: The carrying capacity of homes

\begin{tabular}{|c|c|c|c|c|c|}
\hline S.N. & Name & Address & Capacity & Residents & Remarks \\
\hline 1 & $\begin{array}{|lr|}\text { Old } & \text { Age } \\
\text { Management } \\
\text { and } & \text { Social } \\
\text { Welfare } & \text { Trust } \\
\end{array}$ & Kathmandu & 21 & 19 & $\begin{array}{l}\text { Women } \\
\text { only/Free }\end{array}$ \\
\hline 2 & \begin{tabular}{|l} 
Matatirtha \\
Briddhashram \\
Samiti \\
\end{tabular} & Kathmandu & 20 & 19 & $\begin{array}{l}\text { Women } \\
\text { only/Free }\end{array}$ \\
\hline 3 & \begin{tabular}{|l|} 
Divine Service \\
Home
\end{tabular} & Kathmandu & 20 & 12 & $\begin{array}{l}\text { Women } \\
\text { only/Free }\end{array}$ \\
\hline 4 & $\begin{array}{l}\text { Tapasthali } \\
\text { Briddhashram }\end{array}$ & Kathmandu & 12 & 12 & $\begin{array}{l}\text { Women } \\
\text { only/Free }\end{array}$ \\
\hline 5 & \begin{tabular}{|l|}
$\begin{array}{l}\text { Nisahaya Sewa } \\
\text { Sadan }\end{array}$ \\
\end{tabular} & Kathmandu & 35 & $36^{1}$ & \begin{tabular}{|l|} 
Both \\
sex/Paid
\end{tabular} \\
\hline 6 & \begin{tabular}{|l} 
Siddhi \\
Shaligram \\
Briddhashram \\
\end{tabular} & Bhaktapur & 30 & 15 & $\begin{array}{l}\text { Both } \\
\text { sex/Paid }\end{array}$ \\
\hline 7 & \begin{tabular}{|l} 
Bouddha \\
Briddhashram
\end{tabular} & Kavrepalanchowk & 10 & 9 & \begin{tabular}{|l|} 
Both \\
sex/Paid
\end{tabular} \\
\hline & & & 148 & 122 & \\
\hline
\end{tabular}

Source: Field Survey, 2007

Out of 148-person capacity, 122 seats have been occupied. The homes with serial number 1, 2, 3 and 4 in the table are only for elder women and they do not charge any fees from the residents. In addition, the rest three are paid homes and both of the sex reside there in. The one and only no. 3 home is meant for pure vegetarians.

\footnotetext{
${ }^{1}$ Adjustment
}

All of the homes have specified criteria for entry regarding age, helplessness and like. Major sources of funds involve government's donation, donation from members, and other charity (e.g. mutthi daan - monthly donation of grains by community) including non-monetary helps.

Major problem, according to home personnel, is related with finances. Those homes that provide service free of cost have financial lacking even for adequate feeding provisions and in case of expensive medical treatment. Besides, they have problems regarding the nature of the senior citizens i.e. childish behavior, old age depression and frustration. Most of the homes arrange temple visits, pilgrimage and some have regular yoga and satsang sessions.

\section{The Senior Citizens}

Since four homes in the survey are made only for elder mothers, more than ninety percent of respondents were females. In addition, Nepal, being a patriarchal society (i.e. property inherited to male, access and priorities of males in job and income generating activities), males are in advantage, even though the difficulty at old age for both sex is similar.

Table 2: Respondents by gender and marital status

\begin{tabular}{|l|l|l|l|l|l|l|l|}
\hline SN & & Unmarried & Married & Separated & Divorced & Widow/er & Total \\
\hline 1 & Male & 2 & 2 & 0 & 1 & 1 & $\mathbf{6}$ \\
\hline 2 & Female & 9 & 3 & 5 & 2 & 36 & $\mathbf{5 5}$ \\
\hline 3 & Total & $\mathbf{1 1}$ & $\mathbf{5}$ & $\mathbf{5}$ & $\mathbf{3}$ & $\mathbf{3 7}$ & $\mathbf{6 1}$ \\
\hline
\end{tabular}

Source: Field Survey, 2007

The table shows that more than fifty percent of respondents were widow/er. This fact indicates one of the main reasons for the journey to the elderly homes. Though two couples were observed living in such homes together, being lonely due to the death of the spouse in the old age, when the search 
Dhaulagiri Journal of Sociology and Anthropology Vol.2 | 219

for a new partner is practically impossible, one must have to seek refuge in elderly homes, where cohorts accompany them with more or less similar feelings and life experiences.

Despite the entry of few respondents into such shelters before the age of sixty because of being helpless for different reasons, almost respondents i.e. sixty-six percent have entered at the age sixty to eighty.

Table 3: Respondents by age at entry

\begin{tabular}{|c|l|c|c|}
\hline S.N. & $\begin{array}{c}\text { Age } \\
\text { class }\end{array}$ & Percentage \\
\hline 1 & above 90 & 1 & 1.69 \\
\hline 2 & $80-90$ & 8 & 13.55 \\
\hline 3 & $70-79$ & 16 & 27.11 \\
\hline 4 & $60-69$ & 23 & 38.98 \\
\hline 5 & $\begin{array}{l}\text { below } \\
60\end{array}$ & 11 & 18.64 \\
\hline & TOTAL & $\begin{array}{l}\text { 59 (two respondents not sure about } \\
\text { their age ) }\end{array}$ & \\
\hline
\end{tabular}

Source: Field Survey, 2007

This is such a age or stage, when most of the jobholders retire from the job, most of the people experience the symptoms of old age more significantly and most of them lose spouse.

All of the respondents who were in such homes from more than five to ten years are comfortable with the life in homes, as most of them do not even want to recall the family. They feel that living out of family with cohorts is much better than being hatred or/and burden in the family.

Table 4: Respondents by duration of stay

\begin{tabular}{|l|l|c|c|}
\hline S.N. & Duration & Persons & Percentage \\
\hline 1 & below 1 year & 8 & 13.11 \\
\hline 2 & 1 to 5 years & 25 & 40.98 \\
\hline 3 & 5 to 10 years & 24 & 39.34 \\
\hline 4 & 10 to 15 years & 4 & 6.55 \\
\hline & Total & 61 & 100 \\
\hline
\end{tabular}

Source: Field Survey, 2007

\section{$220 \mid$ Pradeep Acharya}

And in the other hand, some new entries still miss the family and prefer to be reintegrated. But all of them realize the need of the time as being in home is not good for both old and new generation and hence the elderly homes are appropriate place for senior citizens.

During the survey, it has been observed that less than the quarter (only $16.26 \%$ ) of the total respondents have active offspring.

Table 5: Respondents by presence of offspring

\begin{tabular}{|l|l|l|l|}
\hline S.N. & Category & Frequency & Percentage \\
\hline 1 & Child less & 21 & 34.42 \\
\hline 2 & Having children & 16 & 26.22 \\
\hline 3 & Unknown & 15 & 24.59 \\
\hline 4 & Rejection & 9 & 14.75 \\
\hline & Total & 61 & 100 \\
\hline
\end{tabular}

Source: Field Survey, 2007

Besides, another quarter were childless i.e. they never have a kid. Moreover, the rest two categories comprising more than a quarter involve those who have loosed their children, sooner or latter, after giving birth termed as "unknown" here. Moreover, those who rejected to respond regarding children, do not want to recall them, most probably the misbehave from the children that forced them out of family. It is said that "chhora chhori budheskaal ka latthi" (i.e. children are the walking stick at the old age) in Nepalese culture; and that has been evident here.

All of senior mothers in elderly homes were housewives (doing household work, farming) who did not have any secured source of income. 
Table 6: Respondents by past occupation

\begin{tabular}{|l|l|l|l|}
\hline S.N. & Occupation & Frequency & Percentage \\
\hline 1 & Farming/households & 51 & 83.6 \\
\hline 2 & Trade/business & 4 & 6.55 \\
\hline 3 & Government job & 1 & 1.63 \\
\hline 4 & House servants & 5 & 8.19 \\
\hline & Total & 61 & 100 \\
\hline
\end{tabular}

Source: Field Survey, 2007

However, lack of income is no only a factor that makes old age a curse but it matters in both mind and body. First it makes one deprived of physical necessities that money can purchase and second it deepens the feelings of worthlessness in mind.

The government of Nepal, from a decade, has started providing some money as a senior citizen allowance. Out of the 61 only 20 persons are receiving allowance in regular basis. But everyone of the respondents have knowledge about the allowance as well as all of them know it is just nominal but they realize "something is better than nothing".

Table 7: The senior citizen allowance recipients

\begin{tabular}{|l|l|l|l|}
\hline S.N. & Category & Frequency & Percentage \\
\hline 1 & Allowance receiver & 20 & 32.78 \\
\hline 2 & Allowance less & 41 & 67.21 \\
\hline & Total & 61 & 100 \\
\hline
\end{tabular}

Source: Field Survey, 2007

Lack of citizenship certificate seemed to be a major reason behind the lack of access to the allowance for some and others who are away from native districts are not able get the allowance as it is distributed in native place. In addition, an interesting fact must be mentioned is that a pensioner couple does not take the allowance as he feels the allowance is more essential for others who have no source of income.
Weak health and reduction in immunity power are the normal symptoms of the old age but nearly half of the respondents were healthy, fit and fine. They do not have any health problems except occasional common cold and fever. Some of them claim with delight that they have never taken medicine of any kind. It is good news.

Table 8: Health status of the respondents

\begin{tabular}{|l|l|l|l|}
\hline S.N. & Category & Frequency & Percentage \\
\hline 1 & Healthy & 27 & 44.26 \\
\hline 2 & Diseased & 34 & 55.73 \\
\hline & Total & 61 & 100 \\
\hline
\end{tabular}

Source: Field Survey, 2007

Those who are suffering from health problems include chronic diseases like blood pressure, blood sugar, asthma, uric acid, gastric etc; all these are common to most of the old people. They regular visit the doctor and take medicine. Besides, other common problems like hearing, vision have been observed as well as some are paralyzed. Health is the most important aspect of the care of senior citizens. Most of the homes are facing financial problems regarding the treatment of expensive disease like brain hemorrhage and other surgical cases.

\section{Conclusion}

Elderly homes for the welfare of senior citizen are a sociocultural institution with economical, psychological and spiritual dimensions. The care of senior citizen of a society has been a social value from ancient times. For the attainment of such social values, society has set up norms like "we have to respect the seniors, and love the juniors". Moreover, the society as a whole accepts it as everyone has to be old one day. However, in reality, values sometimes contradict 


\section{4 | Pradeep Acharya}

between individual and society, between generations due to various socio-economic factors. Such a value differentiation is what makes elderly citizen a problem and care of them a challenge. Thus, the best option is to encourage and create environment for the establishment of elderly homes at community levels.

Elderly homes and such shelters in terms of their physical and social environment should not be like a compulsive refuge. Criteria for a model old age home (like permanent building, necessary infrastructures and space, appropriate catering system, regular health care and medicines, provision for mental and physical relaxation such yoga, pilgrimages) should be set up and strictly followed. In addition to this growth and development in old age too can be made possible by providing due importance to their knowledge, skills and their utilization. For such homes to develop the existing effort of government and non-government sectors is not sufficient; private sector involvement has been necessary. Last but not the least it can be a potential area of investment for private sector.

It can be straightforwardly confirmed that the elders or the senior citizens always with to live in with their family (children, grand children, spouses) and it is what everyone wants to. But owing to practical circumstances such as some may not have a family; those who have may not be socioeconomically strong enough to carry on their cost of care at the expense of their children, career etc; socio-economically strong ones may have some other personal values and priorities; and some elders themselves are not interested to live in the family with everyday worry of children and family activities. Thus homes for the care senior citizen has been a basic socio-cultural institution like school for educating children. As Bhandari (2061) states that safe and secured old age is not that much different from the concept of 'safe motherhood'.

It is said that "budhabudhi ko sathi ketaketi" (i.e. children are the friend of elder); in fact the stress created due to unoccupied time and depression during old age can be to great extent reduced if they are kept around children, the new comer of a society. In addition, it is also said "kura sunnu budha ko..."(i.e. listen to the talks of elders...) as they are full of past life experiences. Children, youth can benefit by the talks of senior citizens regarding practical and social life. Thus, one of the easy methods to ease the life of elders could be making elderly homes and school in close touch. It also makes the children and youth respect and help senior citizens.

Developing countries like Nepal need to develop senior citizen welfare program in ways compatible with maintaining the cultural values and enhancing the living standard of the elders. Day by day changing needs of industrialization, urbanization created over society should be integrated in existing cultural values with necessary modification. In addition to this, the existing nominal senior citizen allowance must be at least doubled and distribution system made scientific and accessible to the needy elders. Above all the senior citizen should feel like 'seniors' not 'old and obsolete' by making them active in any kind of stress less activities. Age of retirement should not be merely based on the years passed but scientifically set depending upon the capacity, health condition of the individual and requirements of the job i.e. it should be made voluntary not compulsive. Regarding all these, government of Nepal has recently declared to establish a model old age home in Kathmandu in near future. 


\section{Reference}

Bhanman, T.R. (2006). Promotion of Spiritual Health for the Elderly, EMPOWERMENT, Year 5 Vol. 1 Issue 8 April May 2006, A journal of Ministry of Women, Children and Social Welfare, Government of Nepal, Kathmandu, Nepal (pp 36-8)

GEWON (2007). The Senior Citizens and the Elderly Homes around Kathmandu; A survey,_an unpublished report, Geront World Nepal, Kathmandu, Nepal

MWCSW, Government of Nepal (2002). Senior Citizens Policy and Working Policy, Kathmandu, Nepal

Poudel, Nirakar (2004). Problems of Elderly Population: www.nepalnews.com

Shrestha, Menaka Rajbhandari (2004). Problems and Questions of Ageing Population; Nepal University Teacher's Association (NUTA) journal, Vol. 3 No. 3, December 2004, Kathmandu, Nepal (pp 112-122)

Swar, Sushila (2002). Speech of Government of Nepal in International Conference on Ageing, Second World Assembly on Ageing, 9th April, Madrid, Spain

Tenth Plan, Government of Nepal

UNO/MWCSW (2002). Madrid International Plan of Action

भण्डारी, ऋतुराज (२०६१) । बुढ़यौली, सशक्तिकरण वर्ष ३ अकं ६ पुस २०६१, (पषष्ठ ५-१२) काठमांडौ: नेपाल सरकार, महिला बालबालिका तथा समाजकल्याण मत्त्रालय ।

नेपाल सरकार (२०६२)। ज्येष्ठ नागरिक राष्ट्रिय कार्ययोजना । काठमांडौ: महिला बालबालिका तथा समाजकल्याण मत्त्रालय।

\section{6 | Pradeep Acharya}

नेपाल सरकार (२०६१) । नेपालका ज्येष्ठनागरिक बृद्धवृद्धा सम्बन्धि संघसंस्थाहरुको परिचयात्मक पुस्तिका, शान्ति आश्रम, काठमांडौ, नेपाल

नेपाल सरकार (२०६१) । नेपालका ज्येष्ठनागरिक बृद्धवृद्धा सम्बन्धि संघसंस्थाहरुको परिचयात्मक पुस्तिका, शान्ति आश्रम, काठमांडौ, नेपाल 
